\title{
Dynamic Capability of an Operating Stirling Convertor
}

Thomas W. Goodnight, William O. Hughes, and Mark E. McNelis Glenn Research Center, Cleveland, Ohio 
Since its founding, NASA has been dedicated to the advancement of aeronautics and space science. The NASA Scientific and Technical Information (STI) Program Office plays a key part in helping NASA maintain this important role.

The NASA STI Program Office is operated by Langley Research Center, the Lead Center for NASA's scientific and technical information. The NASA STI Program Office provides access to the NASA STI Database, the largest collection of aeronautical and space science STI in the world. The Program Office is also NASA's institutional mechanism for disseminating the results of its research and development activities. These results are published by NASA in the NASA STI Report Series, which includes the following report types:

- TECHNICAL PUBLICATION. Reports of completed research or a major significant phase of research that present the results of NASA programs and include extensive data or theoretical analysis. Includes compilations of significant scientific and technical data and information deemed to be of continuing reference value. NASA's counterpart of peerreviewed formal professional papers but has less stringent limitations on manuscript length and extent of graphic presentations.

- TECHNICAL MEMORANDUM. Scientific and technical findings that are preliminary or of specialized interest, e.g., quick release reports, working papers, and bibliographies that contain minimal annotation. Does not contain extensive analysis.

- CONTRACTOR REPORT. Scientific and technical findings by NASA-sponsored contractors and grantees.
- CONFERENCE PUBLICATION. Collected papers from scientific and technical conferences, symposia, seminars, or other meetings sponsored or cosponsored by NASA.

- SPECIAL PUBLICATION. Scientific, technical, or historical information from NASA programs, projects, and missions, often concerned with subjects having substantial public interest.

- TECHNICAL TRANSLATION. Englishlanguage translations of foreign scientific and technical material pertinent to NASA's mission.

Specialized services that complement the STI Program Office's diverse offerings include creating custom thesauri, building customized data bases, organizing and publishing research results ... even providing videos.

For more information about the NASA STI Program Office, see the following:

- Access the NASA STI Program Home Page at http://www.sti.nasa.gov

- E-mail your question via the Internet to help@sti.nasa.gov

- Fax your question to the NASA Access Help Desk at 301-621-0134

- Telephone the NASA Access Help Desk at 301-621-0390

- Write to:

NASA Access Help Desk

NASA Center for AeroSpace Information 7121 Standard Drive

Hanover, MD 21076 


\section{Dynamic Capability of an Operating Stirling Convertor}

Thomas W. Goodnight, William O. Hughes, and Mark E. McNelis Glenn Research Center, Cleveland, Ohio

Prepared for the

35th Intersociety Energy Conversion Engineering Conference sponsored by the American Institute of Aeronautics and Astronautics Las Vegas, Nevada, July 24-28, 2000

National Aeronautics and Space Administration

Glenn Research Center 


\section{Acknowledgments}

The authors acknowledge the support and expertise of Richard Shaltens, Jeff Schreiber, Lanny Thieme, Steve Geng,

Lee Mason and Ken Mellott/NASA Glenn Research Center, the NASA Glenn Research Center SDL technical staff, Rich Furlong/DOE, Maury White and Ian Williford/STC, and Kurng Chang/JPL. A special note of thanks goes to the SDL's test engineer Sergey Samorezov/Zin Technologies for his expertise in producing and analyzing the test data from this test program.

Available from

NASA Center for Aerospace Information 7121 Standard Drive Hanover, MD 21076

Price Code: A03
National Technical Information Service 5285 Port Royal Road Springfield, VA 22100

Price Code: A03

Available electronically at http://gltrs.grc.nasa.gov/GLTRS 


\title{
DYNAMIC CAPABILITY OF AN OPERATING STIRLING CONVERTOR
}

\author{
Thomas W. Goodnight*, William O. Hughes*†, Mark E. McNelis*‡ \\ National Aeronautics and Space Administration \\ Glenn Research Center \\ Cleveland, Ohio 44135
}

\begin{abstract}
The NASA John H. Glenn Research Center and the U.S. Department of Energy are currently developing a Stirling convertor for use as an advanced spacecraft power system for future NASA deep-space missions. NASA Headquarters has recently identified the Stirling technology generator for potential use as the spacecraft power system for two of NASA's new missions, the Europa Orbiter and the Solar Probe missions (planned for launch in 2006 and 2007 respectively).
\end{abstract}

As part of the development of this power system, a Stirling Technology Demonstration Convertor was vibration tested at NASA John $\mathrm{H}$. Glenn Research Center to verify its survivability and capability of withstanding the harsh dynamic environment typically seen by the spacecraft when it is launched by an expendable launch vehicle.

The Technology Demonstration Convertor was fully operational (producing power) during the random vibration testing. The output power of the convertor and other convertor performance indicators were measured during the testing, and these results are discussed in this paper. Numerous accelerometers and force gauges also were used to provide information on the dynamic characteristics of the Technology Demonstration Convertor and as an indication of any possible damage due to the vibration. These measurements will also be discussed in this paper.

The vibration testing of the Stirling Technology Demonstration Convertor was extremely successful. The Technology Demonstration Convertor survived all its vibration testing with no structural damage or functional performance degradation. As a result of this testing, the Stirling convertor's capability to withstand vibration has been demonstrated, enabling its usage in future spacecraft power systems.

\footnotetext{
*Aerospace Engineer

${ }^{\dagger}$ Associate Fellow, AIAA

${ }^{\ddagger}$ Senior Member, AIAA
}

\section{INTRODUCTION}

NASA John H. Glenn Research Center (GRC) and the U.S. Department of Energy (DOE) are currently developing a Stirling convertor for an advanced radioisotope power system that will provide spacecraft on-board electric power for NASA deep-space missions. Stirling Technology Company (STC) of Kennewick, WA is under contract to DOE to develop a radioisotope Stirling convertor. NASA GRC is providing technical consultation for this effort based on their expertise in Stirling technologies dating back to the mid-1970's.

In May 2000, NASA Headquarters selected the Stirling technology generator as an alternative space power system to Radioisotope Thermoelectric Generators (RTGs). The Stirling technology generator may potentially be used as the spacecraft power system for two new NASA deep-space missions. These are the Europa Orbiter and the Solar Probe missions, which are planned for launch in 2006 and 2007, respectively.

The Stirling system is an attractive alternative to the RTG system. Due to the Stirling system's efficiency (over 20 percent) just one-third the amount of Plutonium is required compared to the RTGs, thereby significantly reducing nuclear fuel cost.

Multiple Stirling units have demonstrated convertor power, efficiency and long life. Currently, one STC terrestrial radioisotope Stirling convertor is operating maintenance-free and without performance degradation after over 53,000 hours (6+ years). Such long lifetimes are required for deep-space missions to the outer planets where solar power is not an option.

Figure 1 illustrates the basic concepts of a Stirling convertor. Designing this convertor with long life and high reliability entails eliminating wear mechanisms and the proper selection and verification of materials. References 1 and 2 provide further insight into Stirling technology and current developmental efforts. 
Before this convertor could be selected as a viable space-flight power system, a test program was needed to determine whether it could survive and function after exposure to the harsh launch vibration environment.

A spacecraft, and the components mounted to it, are exposed to both direct and indirect random vibration during its launch on an expendable launch vehicle. Random vibration from the vehicle's engines and rockets are directly transmitted through the vehicle to the spacecraft via its structural connection path. Usually however it is the indirect vibration that is the dominant source of random vibration to the spacecraft. This vibration is produced by the acoustic pressure waves produced during the vehicle's liftoff. These waves are transmitted through the vehicle's payload fairing protective layer and impinge on the spacecraft. It is typical for spacecraft to be exposed to overall sound pressure levels of 135 to 145 decibels $(\mathrm{dB})$ during a liftoff. (This compares to a level of $100 \mathrm{~dB}$ that is produced by a modern jet fly-over at 1500 feet. On the decibel scale, every increase of $3 \mathrm{~dB}$ is a doubling of the mean square acoustic pressure.)

The high acoustic levels produced during the launch results in significant vibration to the spacecraft and its components. It is for this reason that the Stirling convertor underwent random vibration testing.

To address this issue a DOE/STC 55-We (electric watt) Stirling Technology Demonstration Convertor (TDC) was tested at NASA GRC's Structural Dynamics Laboratory (SDL). The TDC's heat source was electricity, not nuclear fuel. During this test program, the TDC was exposed to high random vibration levels and durations that simulated the maximum expected launch vibration.

\section{VIBRATION TEST DESCRIPTION}

On November 29-December 2, 1999 vibration tests were performed on the Stirling TDC. The testing followed the requirements of the test plan (Ref. 3). The Stirling TDC was supported in a specially made test fixture, as shown in Figure 2. This fixture was, in turn, attached to a slip table driven by a MB Dynamics Model C210 (28,000 pound-force) horizontal electrodynamic shaker. Testing was performed in both the lateral (X, perpendicular to the TDC's piston stroke) and axial (Y, direction of TDC's piston stroke) directions. The Stirling TDC was fully operational (producing power) during the vibration tests.
Two accelerometers located on the test fixture were used to control the vibration test input. Eleven other accelerometers, located on the fixture and TDC, were used to measure the response. The TDC was mounted in its test fixture by eight-force gauge measuring bolts.

Other non-vibration measurements were recorded during the testing to monitor the convertor's performance. These measurements included the input voltage and current at the heater end, the output voltage and current at the alternator end, the average output electric power, and the TDC's temperature and internal dynamic pressure.

Since little was known about the TDC's capability to withstand vibration, it was decided to incrementally test it to higher random vibration levels. Thus the TDC was initially tested to a modified workmanship (NASASTD-7001) level of 6.8 Grms. This is a level of vibration that historically has been shown to detect hidden flaws or defects in materials, production or assembly for electronic and mechanical spaceflight hardware components.

Next the TDC was shaken to the higher Jet Propulsion Laboratory (JPL) vibration levels $(-6 \mathrm{~dB},-3 \mathrm{~dB}$ and $0 \mathrm{~dB}$ relative to the qualification level of $12.3 \mathrm{Grms}$ ). JPL's standard method is to test qualify its hardware to levels which are $3 \mathrm{~dB}$ greater than the maximum expected flight environment. Thus the "qualification $-3 \mathrm{~dB}$ " level represents a "flight" level. However, due to unknowns in both the launch vehicle and in the spacecraft mounting details, the JPL "flight" test levels should be representative of typical flight levels seen by a spacecraft's components during liftoff. The qualification test levels used for these tests are considered to provide margin above this typical "flight".

These test levels are shown in Figure 3. All random test durations were for one minute per axis, except for the 3 minutes per axis qualification tests.

To closely monitor the performance and structural integrity of the TDC, low-level $(0.25 \mathrm{~g})$ sine sweep tests were performed before and after each major random vibration test. This provided a means of observing any structural changes caused by the random testing. Functional and electrical tests and visual inspections were also performed before and after each dynamic test (random or sine sweep) to monitor the TDC's functional performance and structural integrity. 


\section{VIBRATION TEST RESULTS}

\section{General}

Figure 4 shows the test matrix and the order in which the tests were performed. The control of the test input was excellent for all tests.

The objectives of this test program were met and exceeded. The Stirling TDC was exposed to significant (greater than expected launch) vibration test levels and durations, and successfully passed post-test functional testing. The most severe test was to the JPL qualification test levels $\left(12.3 \mathrm{Grms}, 0.2 \mathrm{~g}^{2} / \mathrm{Hz}\right.$ from 50 to $250 \mathrm{~Hz}, 3$ minutes/axis, in both the axial and lateral directions). As a comparison, the RTGs used for the Galileo/Ulysses/Cassini missions were test qualified to 7.7 Grms (laterally) and $6.1 \mathrm{Grms}$ (axially).

The Stirling TDC survived all dynamic testing with no structural damage or functional performance degradation. The Stirling TDC operated at full-stroke and produced power during all its vibration testing. Dithering (reducing) the piston stroke was not necessary. The TDC produced full power at the end of each and every vibration test.

\section{Power Performance}

The power produced by the Stirling TDC did vary during testing. During the lateral random vibration testing, a slow steady degradation of output power was observed (on average) as a function of increasing vibration test input, but the power immediately returned to the full and stable level when each vibration test ended. This observed trend is illustrated in Figure 5. The mean and standard deviation (sigma) statistics were numerically calculated from periodically observed data taken from a wattmeter during each test. The "mean \pm 2 sigma" levels statistically represents the levels that the observed power should be recorded $95.45 \%$ of the time. This measure closely correlated with the actual range of the output power data from the wattmeter. The change in power during the lateral testing is believed due to the increased friction and leakage losses caused by the lateral vibration.

During the axial direction random vibration testing, the power output remained, on average, at full level, as shown in Figure 6. Instantaneous surges and dips were observed however, which were believed to be due to shaking the TDC in the direction of its piston stroke. These variations as measured by the standard deviation (sigma) calculation were larger in the axial direction than in the lateral direction. Once again, the power immediately returned to the full and stable level when each vibration test ended.

The output power plotted as a function of time is shown in Figures 7 to 9 for three different cases. Arbitrary time slices of 0.2 seconds are shown for illustration purposes, although the signal's frequency characteristics were consistent throughout the entire test duration. These instantaneous output power time histories were computed by multiplying the instantaneous output voltage by the instantaneous output current. The amplitudes are normalized and plotted on the same scale.

Figure 7 shows the "solo" production or the output power time history that is produced with no external vibration. This time plot shows a primary frequency of $158 \mathrm{~Hz}$, or 2 times the piston stroke frequency of $79 \mathrm{~Hz}$. It also shows a slight modulation frequency of $19 \mathrm{~Hz}$.

Figure 8 shows the time history for the qualification test level in the lateral direction. Although the relative amplitude (compared to solo) is reduced, as expected from Figure 5, the frequency content of $158 \mathrm{~Hz}$ remains. Now the modulation is more pronounced and occurs at 8 to $9 \mathrm{~Hz}$.

Likewise, Figure 9 shows the time history for the qualification $-6 \mathrm{~dB}$ test level in the axial direction. In this case the average amplitude is comparative to that of the solo condition, as expected from Figure 6. Once again the primary frequency of the output power is $158 \mathrm{~Hz}$, with a modulating frequency of 8 to $9 \mathrm{~Hz}$.

Frequency spectrums of the output power for these three tests were calculated using the entire available time histories. These output power spectral densities are shown in Figures 10 (solo), 11 (qualification in lateral direction) and 12 (qualification $-6 \mathrm{~dB}$ in axial direction). Note though that the amplitude is plotted on a $\log$ axis. Thus each major division is a factor of 10 on amplitude.

Figure 10 shows that $158 \mathrm{~Hz}$ dominates the solo output power, and to a much lesser extent the higher even harmonics of $79 \mathrm{~Hz}(316 \mathrm{~Hz}, 474 \mathrm{~Hz}, 632 \mathrm{~Hz}$ and $790 \mathrm{~Hz}$ ). The presence of the modulating frequency of $19 \mathrm{~Hz}$ and the associated side-bands are also evident. Note that all these frequencies are very sharp and pure (sinusoidal) for the solo condition.

Figure 11 shows the frequency spectrum for the qualification test in the lateral direction. Once again 
note the dominating presence of $158 \mathrm{~Hz}$ and the other even harmonics of $79 \mathrm{~Hz}$. A major difference however is the apparent spreading of the power into the "skirt" of each even harmonic. This spreading is attributable to the vibration excitation slightly distorting the pure piston stroke frequency. This observation should be tempered by remembering the magnitude is on a $\log$ axis. The small side-band frequencies, most notable at $158 \mathrm{~Hz}$, seems to be the modulating effect of the $8 \mathrm{~Hz}$ frequency.

The frequency spectrum for the qualification $-6 \mathrm{~dB}$ test in the axial direction is shown in Figure 12. Similar conclusions on the effects of vibration can be made here as was done for Figure 11.

The output voltage, current and internal dynamic pressure all exhibited similar characteristics under the vibration excitation, peaking at the piston stroke frequency of $79 \mathrm{~Hz}$. Figure 13 shows the frequency spectrum of the output voltage for the lateral direction tests for various test levels (solo, qualification $-6 \mathrm{~dB}$, and qualification). This plot shows that the spreading of the signal (breadth of the skirt) correlates with the level of vibration excitation, as expected.

Figure 14 shows the output current for the qualification $-6 \mathrm{~dB}$ test level for the lateral and axial tests and for the solo condition. Here one sees that vibrating in the axial direction distorts the pure piston stroke even more than the lateral excitation does.

\section{Structural Dynamic Response}

The Stirling TDC structure was found to be dynamically well behaved and linear, with reasonable damping (due to its multi-layered design and inherent internal gas damping). The pre and post sine testing showed no significant changes in the dynamic characteristics of the TDC measurements, due to its exposure to the random environments.

The lateral direction sine sweep data shows a convertor casing structural resonance at $1030 \mathrm{~Hz}$, with a mechanical Q (dynamic amplification) of 5 to 8 . In the axial directions, the sine sweep data shows possible convertor casing/fixture structural resonances at $1492 \mathrm{~Hz}$ and $1730 \mathrm{~Hz}$, with mechanical Q values of 2 to 5 . In both directions, the structural resonances are high enough in frequency to avoid any dynamic coupling problems with the Stirling's piston stroke frequency of $79 \mathrm{~Hz}$. The TDC responded rigidly to the random test input below $350 \mathrm{~Hz}$.
Additionally details on the Stirling TDC's structural dynamic response during the vibration test may be found in References 4 and 5.

\section{POST VIBRATION TESTING EVALUATION}

Following the vibration testing at NASA GRC, the Stirling TDC was operated for an additional 10 million cycles (35 hours) to demonstrate its post-test life. On January 4, 2000 a team of STC, NASA GRC and Lockheed Martin personnel participated in the disassembly and inspection of the TDC unit at STC. This team concluded that there were no areas of concern attributable to the vibration testing (Ref. 6). The bases for their conclusion were: (1) satisfactory alignment for all moving parts and properly retained clearances, (2) no broken parts found inside convertor and intact structural integrity, (3) all fasteners retained adequate tightness, and (4) all post-test electrical measurements were consistent with pre-vibration test values.

\section{STRUCTURAL MOUNTING CONSIDERATIONS}

The Stirling TDC's structural characteristics (refer to Figs. 1 and 2) were utilized in achieving a successful vibration test. The TDC has two bulbous ends, one end larger than the other end. The larger end, the pressure vessel, houses the heavier mass of the linear alternator. The smaller end contains the thermally active working elements of the heater head assembly, including the displacer. A continuous conic section, called the piston housing, is centrally located between these two ends. As tested, the piston housing has two flanges. These two flanges are the only mounting planes for attachment for the test fixture (or for future spacecraft systems). For a flight system, heat will be rejected, via a radiator mount, from the system near the smaller flange. The linear alternator end cap is cantilevered from the larger flange. The center of gravity of the TDC is just outside the large flange on the linear alternator end.

The piston housing is central to the success of the TDC because it contains the piston, and the displacer rod is mounted from the smaller flange. Close clearance pressure seals are used on both the piston and displacer rod. The piston transmits the power generated from the heater head assembly to the linear alternator.

The two flanges at each end of the piston housing provided a choice of a large or small bolt circle for mounting the TDC to the test fixture. The rest of the 
TDC is supported from the piston housing. For ground operations, there is a water loop on the heater head assembly, adjacent to the piston housing, that limited access to the smaller ring. These water loop fittings were well supported during the vibration test to alleviate any vibration concern.

In fixture design, a rigid simulation of the interface is required. In other words, the impedance of the fixture as measured at the mounting face must be large as compared to the mounting flange compliance. For this test program, due to clearance issues and available mounting flanges, the fixture block enveloped the linear alternator (large bulbous end). This allowed sufficient surface area to seat the eight-instrumented force bolts on 0.25 -inch spacers. These bolts were inserted through the large outer-diameter mounting flange and torqued directly to the aluminum fixture block.

For the purposes of system integration, previous Stirling system designs have shown mountings at the small flange. In this test, the water loop fittings made that flange inaccessible. Even if it was accessible however, the larger flange is still highly recommended for future mounting systems from a structural perspective. By mounting from the larger ring, the net results are that the critical clearances and pressure seals of the piston housing were lightly strained and the resulting overhung mass moments (produced in the simulated launch environment vibration) were minimized. Choosing the larger flange for the test mounting condition, in conjunction with the TDC's inherent damping, is thought to be a key contributor to the TDC's successful vibration test.

\section{CONCLUSIONS}

The Stirling convertor is a promising and viable alternative to the RTG for use as an electric on-board power source for future NASA deep-space missions. The vibration testing performed at NASA Glenn Research Center has proven that the Stirling convertor can survive and function after exposure to its expected launch random vibration environment. Both structural integrity and power performance were retained throughout and at the completion of the vibration testing. The structural dynamics of the convertor needs to be considered when integrating it to the rest of the spacecraft power system in order to minimize the vibration loads on critical internal components.

\section{REEERENCES}

1. "Technology Demonstration of a Free-Piston Stirling Advanced Radioisotope Space Power System," M.A. White, S. Qiu, R.W. Olan, and R.M. Erbeznik, Proceedings for the Space Technology \& Applications International Forum (STAIF-99), Albuquerque, New Mexico, 30 January-4 February 1999.

2. "Technology Development for a Stirling Radioisotope Power System," L.G. Thieme, S. Qiu, and M.A. White, NASA/TM-2000209791, March 2000.

3. "Vibration Test Plan to Characterize the TDC Stirling Engine for Future Technology Development," approved by R. Furlong (DOE), M. White (STC), J. Schreiber (NASA GRC), and T. Goodnight (NASA GRC), November 23, 1999.

4. "Technology Demonstrator Convertor (TDC) Stirling Engine, Prototype Unit, Vibration Test Report," S. Samorezov, NASA GRC Test Report SDL-TR-99-37, 24 January 2000.

5. "Vibration Testing of an Operating Stirling Convertor, " by W.O. Hughes, M.E. McNelis, T.W. Goodnight, Proceedings of the Seventh International Congress on Sound and Vibration, Garmisch-Partenkirchen, Germany, July 4-7, 2000, NASA/TM-2000-210526.

6. "STC Convertor Disassembly and Inspection," by L. Mason, NASA GRC memorandum, January 19, 2000. 


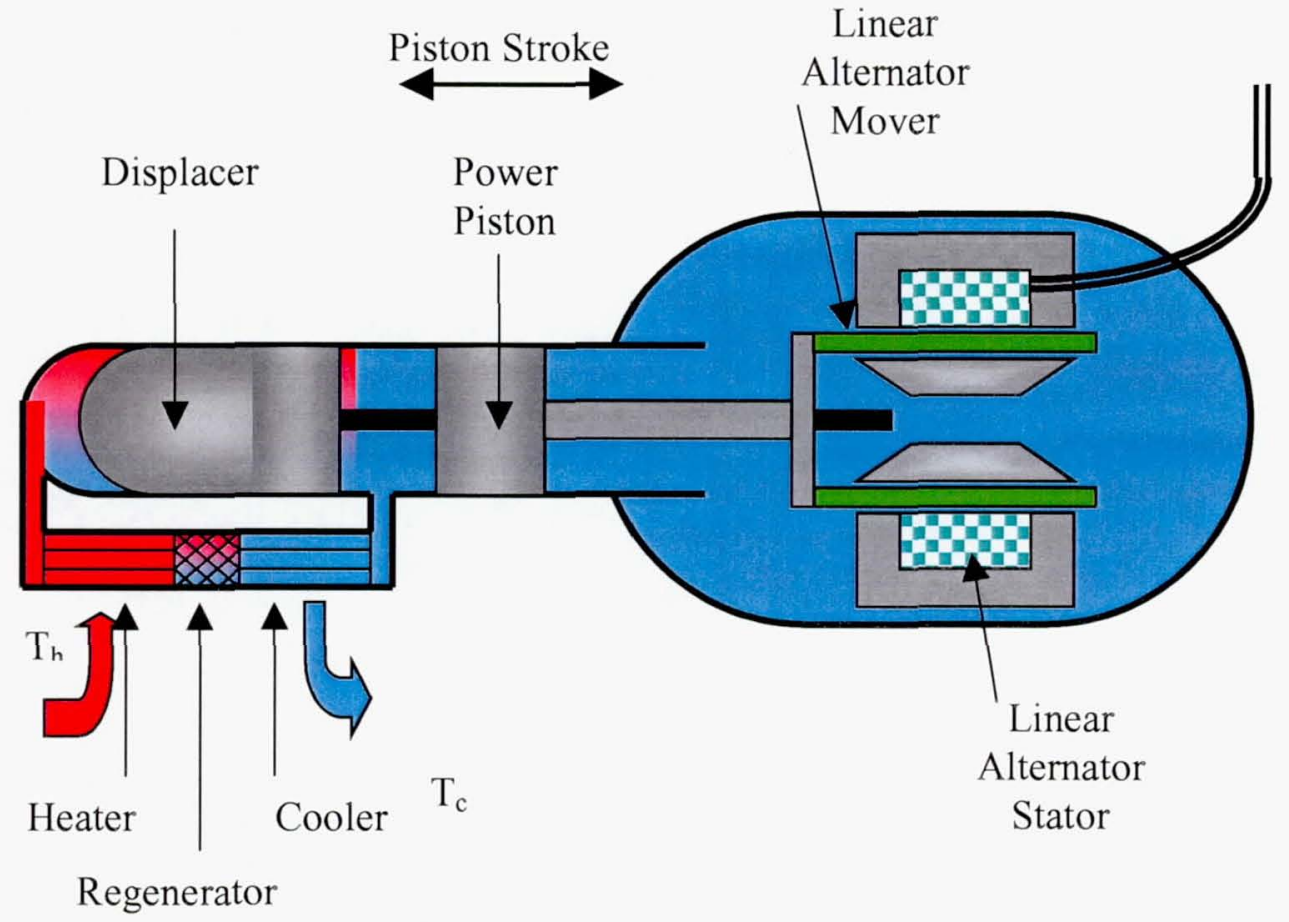

Figure 1. General Free-Piston Stirling Convertor Schematic

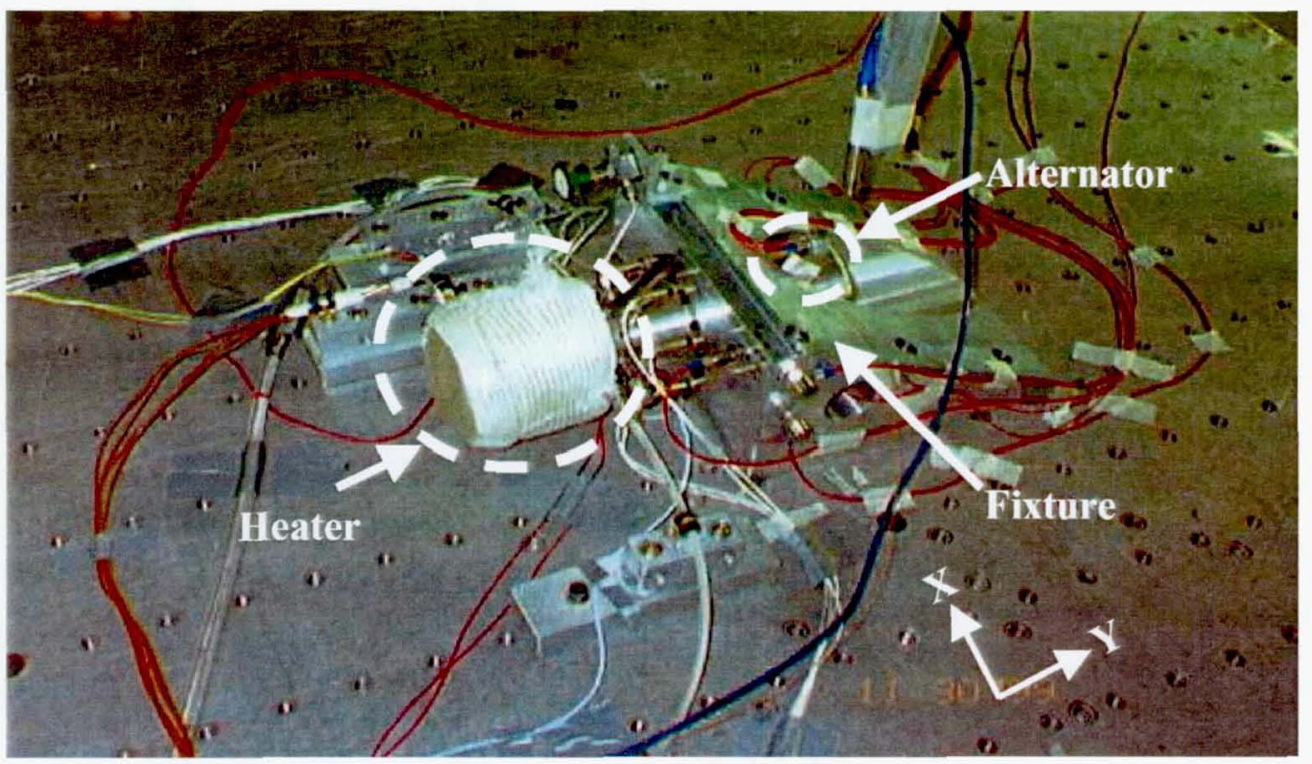

Figure 2. Stirling TDC and Vibration Test Fixture 


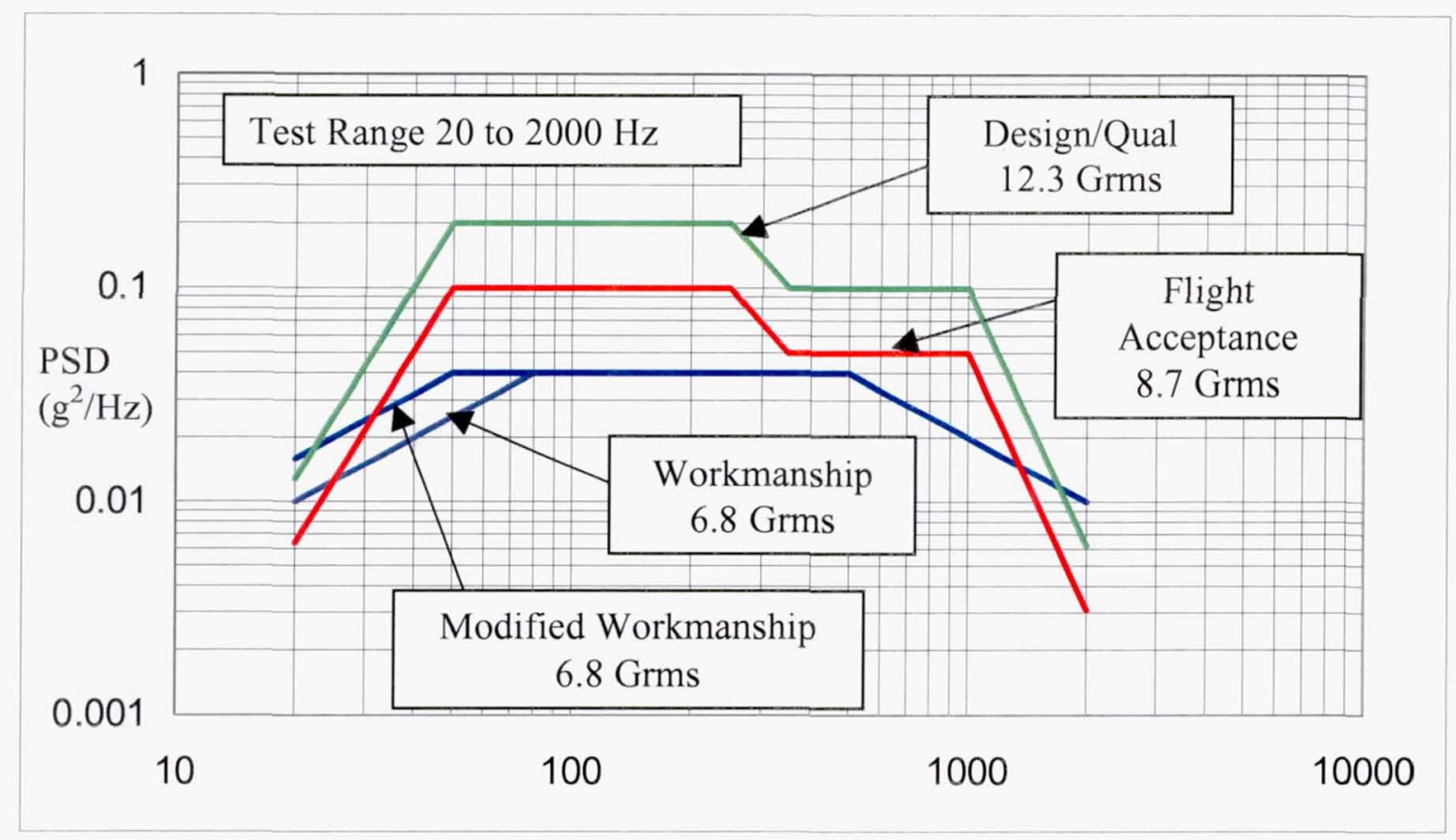

Figure 3. Stirling TDC Random Vibration Test Levels

\begin{tabular}{|c|c|c|c|c|}
\hline $\begin{array}{c}\text { Test } \\
\text { Description }\end{array}$ & $\begin{array}{c}\text { Test } \\
\text { Magnitude }\end{array}$ & Test Duration & $\begin{array}{c}\text { Axial * } \\
\text { Direction }\end{array}$ & $\begin{array}{c}\text { Lateral* } \\
\text { Direction }\end{array}$ \\
\hline Pre Sine Sweep & $0.25 \mathrm{~g}$ & 4 octaves/min & 6 & 1 \\
\hline $\begin{array}{c}\text { Workmanship } \\
\text { Random Vibration }\end{array}$ & $6.8 \mathrm{Grms}$ & $1 \mathrm{~min} / \mathrm{axes}$ & 7 & 2 \\
\hline Post Sine Sweep & $0.25 \mathrm{~g}$ & 4 octaves/min & 8 & 3 \\
\hline Sine Sweep & $0.375 \mathrm{~g}$ & 4 octaves/min & 9 & 4 \\
\hline Sine Sweep & $0.50 \mathrm{~g}$ & 4 octaves/min & 10 & 5 \\
\hline Pre Sine Sweep & $0.25 \mathrm{~g}$ & 4 octaves/min & 11 & 16 \\
\hline $\begin{array}{c}\text { JPL Random Vibration } \\
\text { Qualification - 6 dB }\end{array}$ & $6.2 \mathrm{Grms}$ & $1 \mathrm{~min} / \mathrm{axes}$ & 12 & 17 \\
\hline $\begin{array}{c}\text { JPL Random Vibration } \\
\text { Qualification - 3 dB = Flight }\end{array}$ & $8.7 \mathrm{Grms}$ & $1 \mathrm{~min} / \mathrm{axes}$ & 13 & 18 \\
\hline $\begin{array}{c}\text { JPL Random Vibration } \\
\text { Qualification }\end{array}$ & $12.3 \mathrm{Grms}$ & $3 \mathrm{~min} / \mathrm{axes}$ & 14 & 19 \\
\hline Post Sine Sweep & $0.25 \mathrm{~g}$ & 4 octaves/min & 15 & 20 \\
\hline
\end{tabular}

*Order of testing; Random tests from 20 to $2000 \mathrm{~Hz}$; Sine tests from 5 to $2000 \mathrm{~Hz}$.

Figure 4. Stirling TDC Vibration Test Matrix 
Stirling TDC Lateral Testing

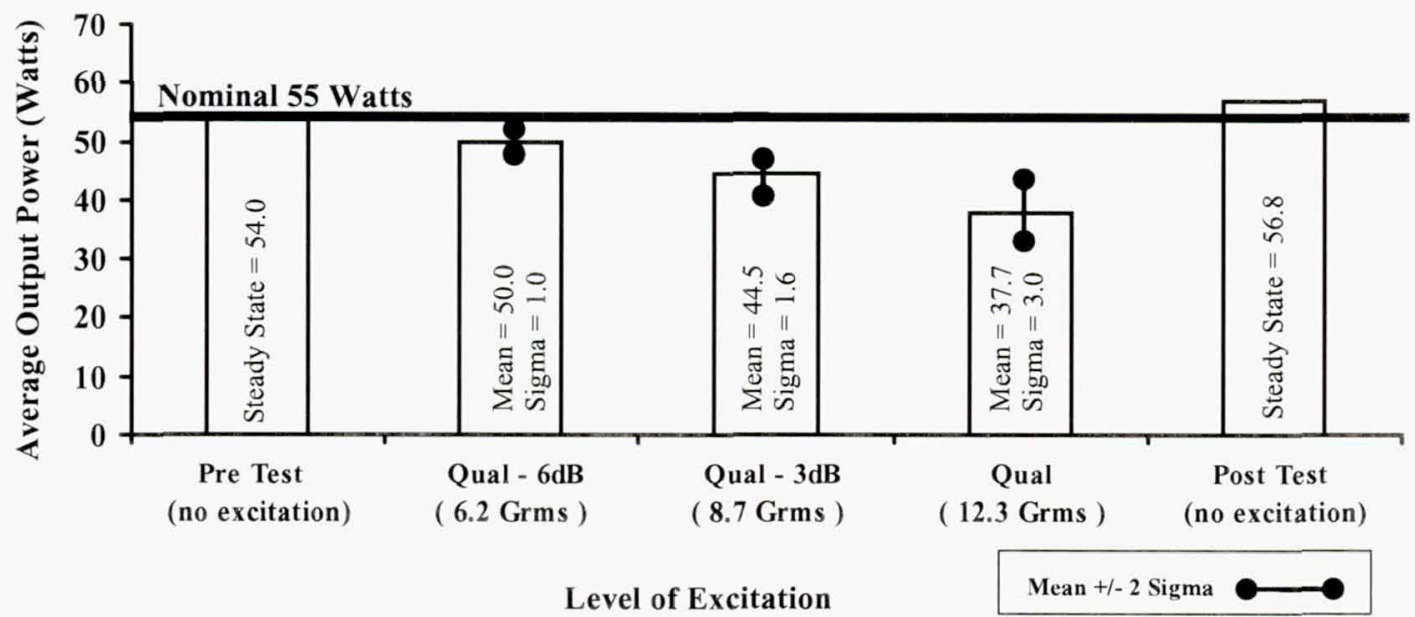

Figure 5. Comparison of Output Power versus Level of Input Vibration in Lateral Direction.

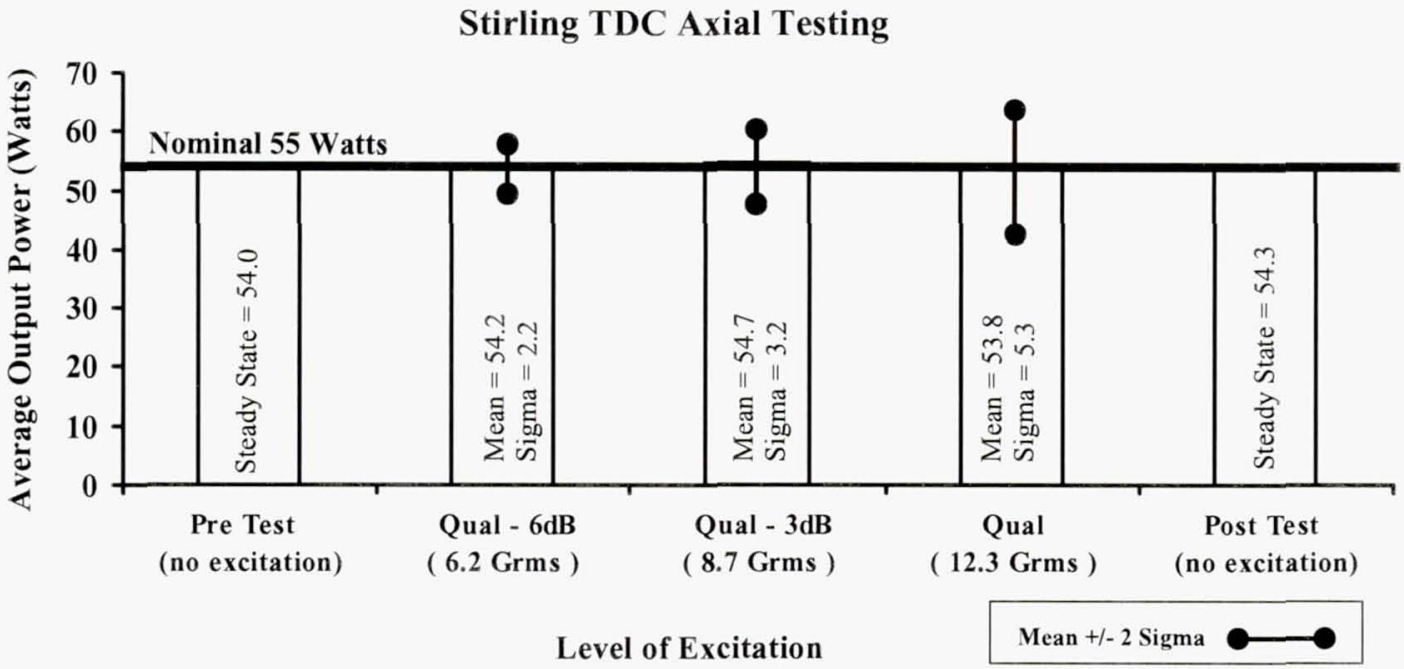

Figure 6. Comparison of Output Power versus Level of Input Vibration in Axial Direction. 


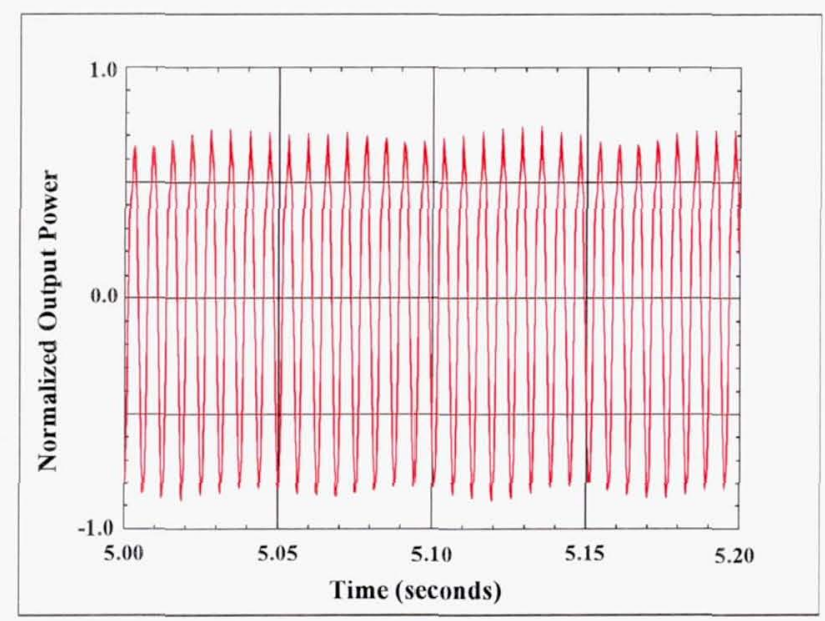

Figure 7. Normalized Output Power

Time Plot for Solo TDC (no external vibration)

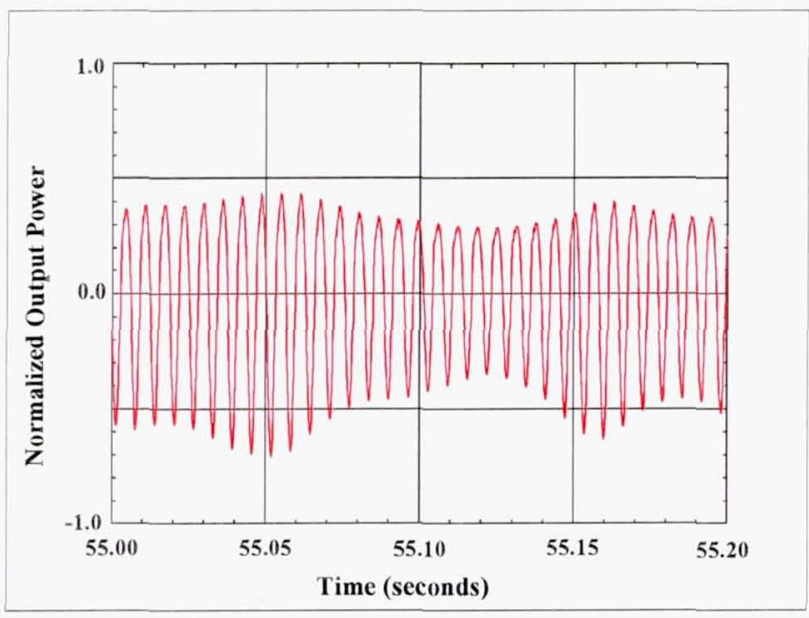

Figure 8. Normalized Output Power

Time Plot for Qualification Test in Lateral Direction

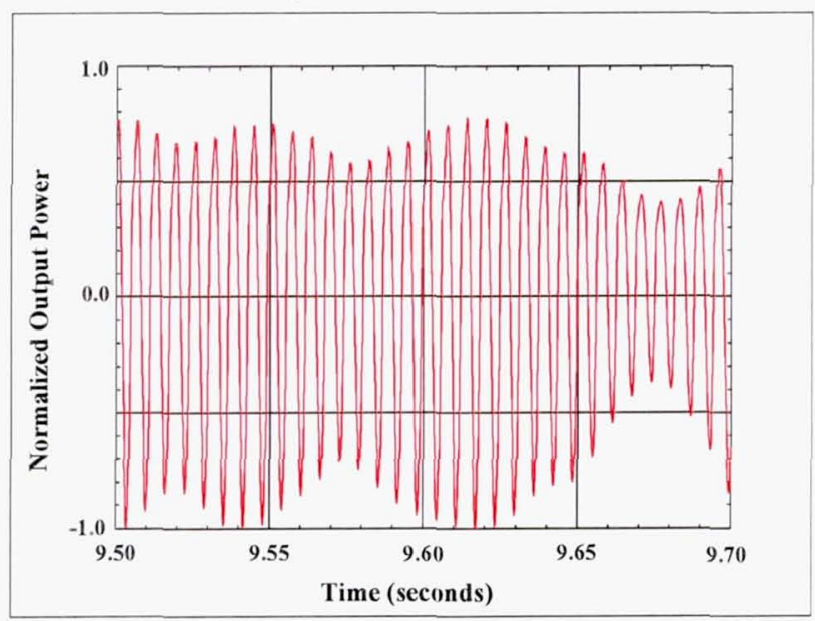

Figure 9. Normalized Output Power

Time Plot for Qualification-6dB Test in Axial Direction 


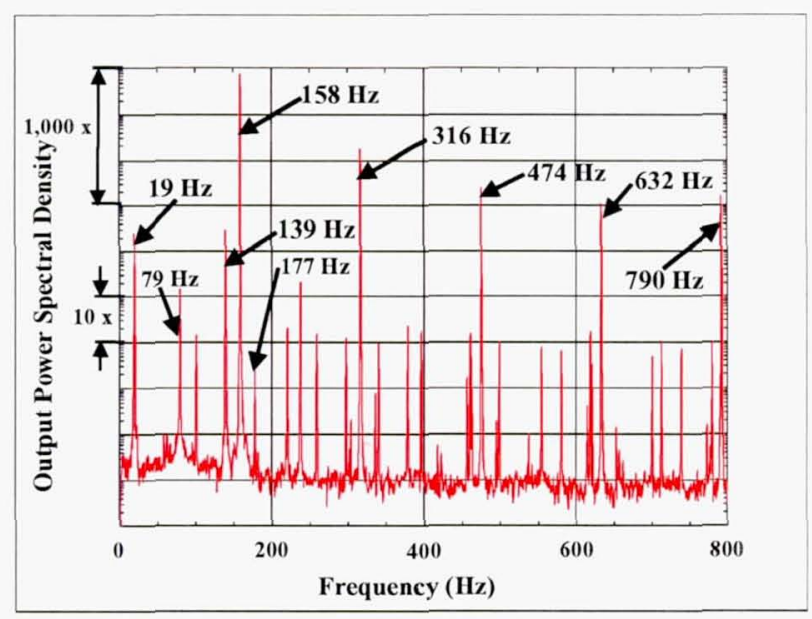

Figure 10. Frequency Spectrum of Output Power for Solo TDC (no external vibration)

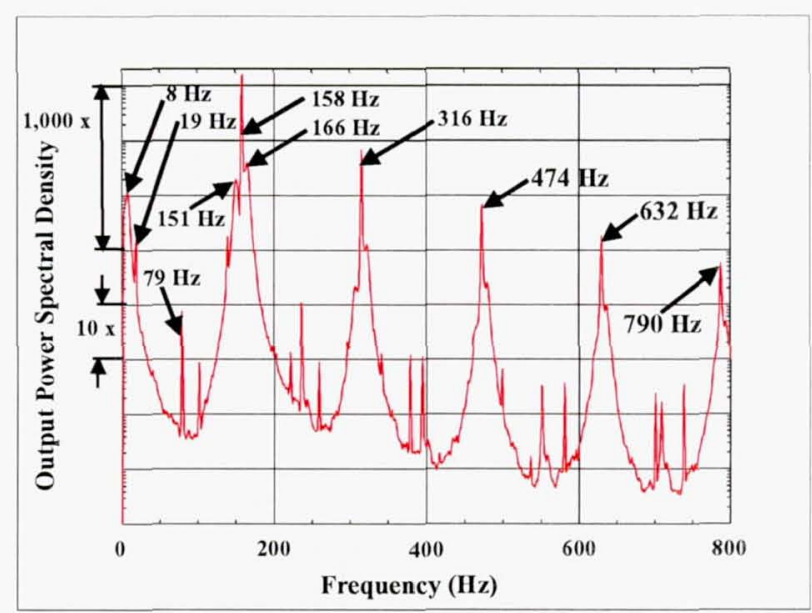

Figure 11. Frequency Spectrum of Output Power for Qualification Test in Lateral Direction

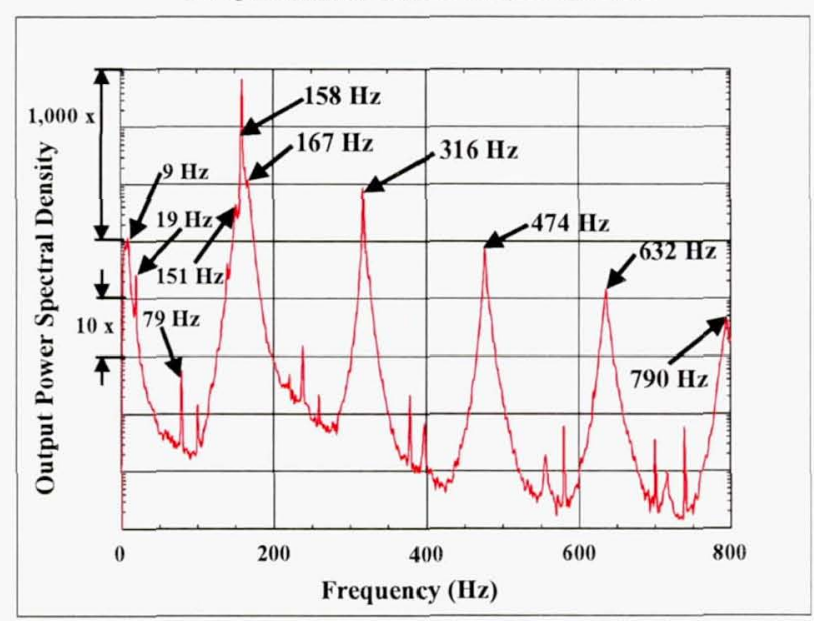

Figure 12. Frequency Spectrum of Output Power for Qualification-6dB Test in Axial Direction 


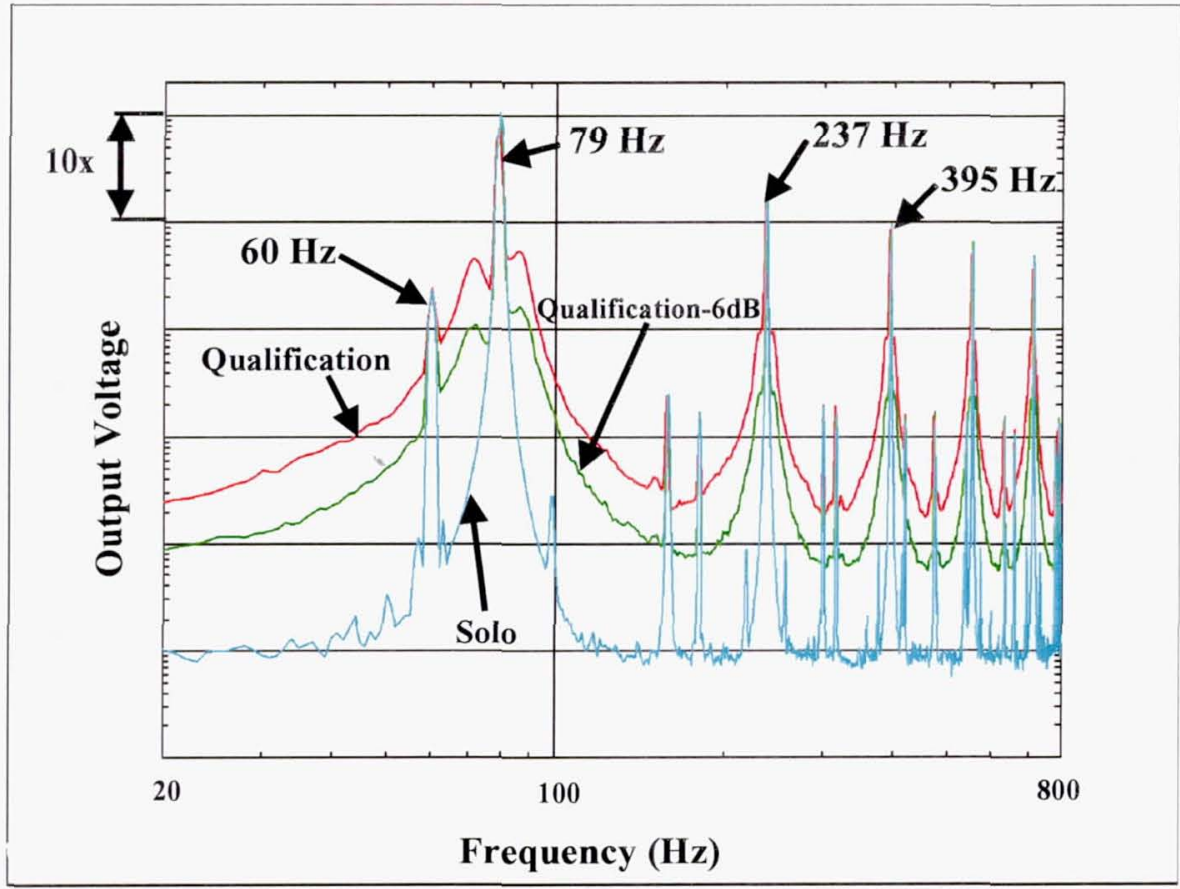

Figure 13. Effect of External Vibration Level on Output Voltage for Lateral Tests

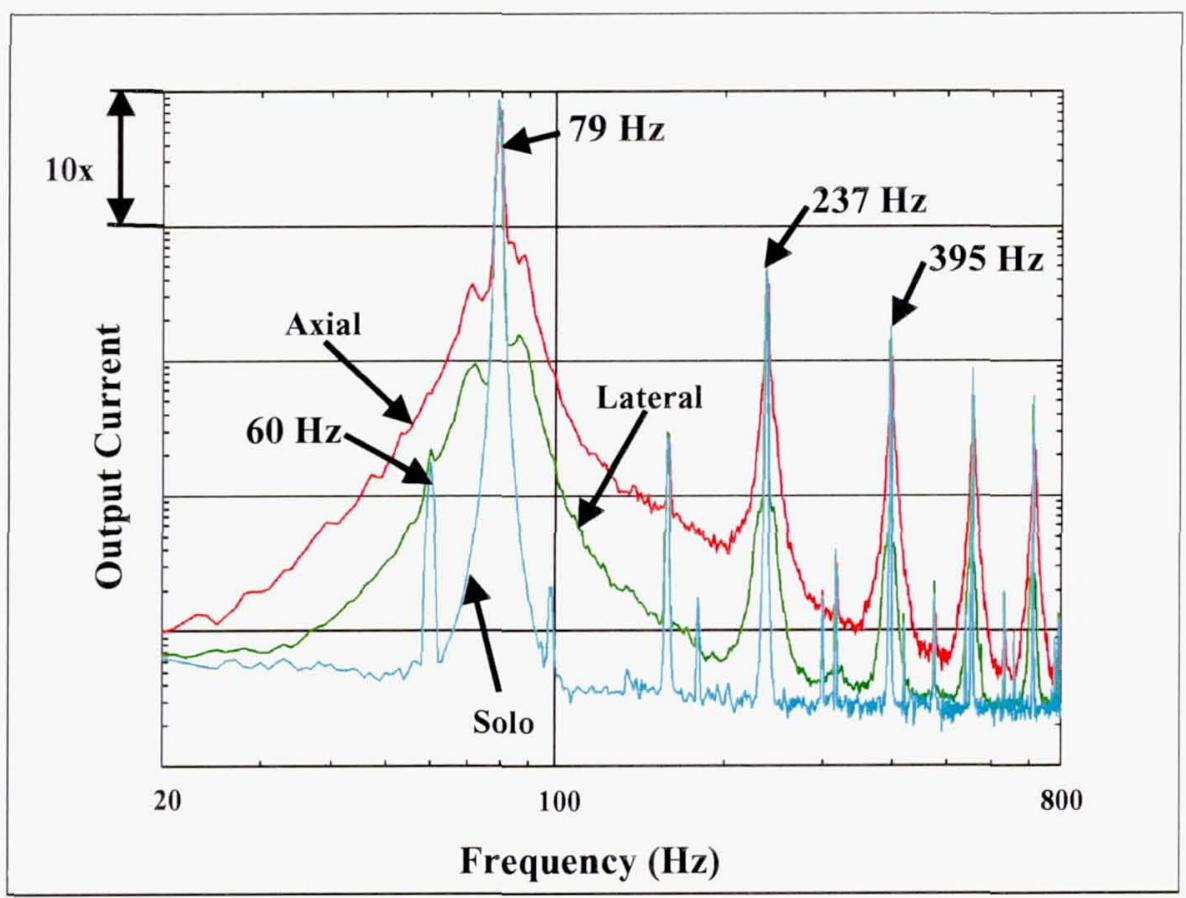

Figure 14. Effect of Test Direction on Output Current for Qualification-6dB Tests 
Public reporting burden for this collection of information is estimated to average 1 hour per response, including the time for reviewing instructions, searching existing data sources, gathering and maintaining the data needed, and completing and reviewing the collection of information. Send comments regarding this burden estimate or any other aspect of this collection of information, including suggestions for reducing this burden, to Washington Headquarters Services, Directorate for Information Operations and Reports, 1215 Jefferson Davis Highway, Suite 1204, Arlington, VA 22202-4302, and to the Office of Management and Budget, Paperwork Reduction Project (0704-0188), Washington, DC 20503.

\begin{tabular}{|l|r|r|}
\hline 1. AGENCY USE ONLY (Leave blank) & $\begin{array}{r}\text { 2. REPORT DATE } \\
\text { November } 2000\end{array}$ & $\begin{array}{r}\text { 3. REPORT TYPE AND DATES COVERED } \\
\text { Technical Memorandum }\end{array}$ \\
\hline
\end{tabular}

\section{TITLE AND SUBTITLE}

5. FUNDING NUMBERS

Dynamic Capability of an Operating Stirling Convertor

6. AUTHOR(S)

WU-839-20-00-00

Thomas W. Goodnight, William O. Hughes, and Mark E. McNelis

\section{PERFORMING ORGANIZATION NAME(S) AND ADDRESS(ES)}

National Aeronautics and Space Administration

John H. Glenn Research Center at Lewis Field

Cleveland, Ohio 44135-3191

9. SPONSORING/MONITORING AGENCY NAME(S) AND ADDRESS(ES)

National Aeronautics and Space Administration

Washington, DC 20546-0001
8. PERFORMING ORGANIZATION REPORT NUMBER

E-12504
10. SPONSORING/MONITORING AGENCY REPORT NUMBER

NASA TM-2000-210527

AIAA-2000-2839

11. SUPPLEMENTARY NOTES

Prepared for the 35th Intersociety Energy Conversion Engineering Conference sponsored by the American Institute of Aeronautics and Astronautics, Las Vegas, Nevada, July 24-28, 2000. Responsible person, William O. Hughes, organization code 7735, 216-433-2597.

12a. DISTRIBUTION/AVAILABILITY STATEMENT

12b. DISTRIBUTION CODE

Unclassified - Unlimited

Subject Categories: 18, 20, and 44

Distribution: Nonstandard

Available electronically at http://gltrs.gre.nasa.gov/GLTRS

This publication is available from the NASA Center for AeroSpace Information, 301-621-0390.

\section{ABSTRACT (Maximum 200 words)}

The NASA John H. Glenn Research Center and the U.S. Department of Energy are currently developing a Stirling convertor for use as an advanced spacecraft power system for future NASA deep-space missions. NASA Headquarters has recently identified the Stirling technology generator for potential use as the spacecraft power system for two of NASA's new missions, the Europa Orbiter and the Solar Probe missions (planned for launch in 2006 and 2007 respectively). As part of the development of this power system, a Stirling Technology Demonstration Convertor was vibration tested at NASA John H. Glenn Research Center to verify its survivability and capability of withstanding the harsh dynamic environment typically seen by the spacecraft when it is launched by an expendable launch vehicle. The Technology Demonstration Convertor was fully operational (producing power) during the random vibration testing. The output power of the convertor and other convertor performance indicators were measured during the testing, and these results are discussed in this paper. Numerous accelerometers and force gauges also were used to provide information on the dynamic characteristics of the Technology Demonstration Convertor and as an indication of any possible damage due to the vibration. These measurements will also be discussed in this paper. The vibration testing of the Stirling Technology Demonstration Convertor was extremely successful. The Technology Demonstration Convertor survived all its vibration testing with no structural damage or functional performance degradation. As a result of this testing, the Stirling convertor's capability to withstand vibration has been demonstrated, enabling its usage in future spacecraft power systems.

14. SUBJECT TERMS

Vibration testing; Spacecraft power systems 15. NUMBER OF PAGES

17 6. PRICE CODE A03

\begin{tabular}{|c|c|c|}
\hline $\begin{array}{c}\text { 17. SECURITY CLASSIFICATION } \\
\text { OF REPORT } \\
\text { Unclassified }\end{array}$ & $\begin{array}{c}\text { 18. SECURITY CLASSIFICATION } \\
\text { OF THIS PAGE } \\
\text { Unclassified }\end{array}$ & $\begin{array}{c}\text { 19. SECURITY CLASSIFICATION } \\
\text { OF ABSTRACT } \\
\text { Unclassified }\end{array}$ \\
\hline
\end{tabular}

NSN 7540-01-280-5500 